\title{
Development of Discrete Mathematics Learning Content Using Google Classroom in Mathematics Education Students
}

\author{
Nirfayanti $^{1 *}$, Sugian Nurwijaya ${ }^{2}$, Suarti Djafar ${ }^{3}$, Reski Ramdani ${ }^{4}$, Nely Salu \\ Padang $^{5}$, and Ernawati ${ }^{6}$
}

\begin{abstract}
${ }^{1,6}$ Mathematics Education Department, Muslim University of Maros, Indonesia
${ }^{2}$ Mathematics Education Department, University of Muhammadiyah Bone, Indonesia

${ }^{3}$ Mathematics Education Department, University Muhammadiyah of Enrekang, Indonesia

${ }^{4}$ Mathematics Education Department, Muhammadiyah University of Makassar, Indonesia

${ }^{5}$ STIE Jambatan Bulan, Indonesia

*nirfa@umma.ac.id
\end{abstract}

\begin{abstract}
The type of research used was development research that aims to develop learning content in discrete mathematics courses that are valid, practical, and effective for use in Mathematics Education students. The subjects in this study were students who programmed discrete mathematics courses in the odd semester of the 2020/2021 academic year. The development process in this research refers to the development model adapted fromPlomp, consisting of the initial investigation, design, realization, test, evaluation, and revision phases and implementation. The research instrument used was the learning implementation observation sheet, validation sheet, student response questionnaires, and learning outcome tests. The results of the research both theoretically and empirically show that the assessment tools developed to meet the following criteria: (1) valid according to expert judgment and empirically the instrument items are valid, (2) practical, students respond positively to the instrument being developed, and (3) effective based on the results of student learning tests have reached completeness. The results of research and development of learning content as shown in the above trial results show that the instruments developed have met the criteria of validity, practicality, and effectiveness, as learning content that can be used further by Mathematics Education lecturers in Higher Education
\end{abstract}

Keywords: learning content, discrete mathematics, model plomp, learning outcome.

\section{INTRODUCTION}

The COVID-19 pandemic is the first and foremost health crisis in the world. Many countries have decided to close schools, colleges and universities. The United Nations (UN) became upset by this fact. The international organization headquartered in New York, USA, captures that education is one of the sectors that has been badly affected by the corona virus. Worse yet, it happened at a fast tempo and on a wide scale.

The impact of the corona pandemic has now begun to penetrate the world of education, the central and regional governments have provided policies to close all educational institutions. This was done in an effort to prevent the spread of the corona virus. It is hoped that with all educational institutions not carrying out activities as usual, this can minimize the spread of the Covid-19 disease.

The spread of the corona virus initially had a huge impact on the economic world which was starting to sluggish, but now the impact is also being felt by the world of education. The policies taken by many countries including Indonesia by closing all educational activities have made the government and related institutions have to present an alternative educational process for students 
and students who cannot carry out the educational process at educational institutions.

Covid-19 affected countries are placing national responses in the form of learning platforms and other tools such as distance learning. Currently in Indonesia, several campuses and schools have begun to implement policies for teaching and learning activities from distance or online lectures, one of which is Maros Muslim University.

With the changes and advances in the use of information technology in the world of education, it is possible for educators and students to find their own learning materials via the internet [1]. Today, the role of information technology in providing interactive teaching materials is very necessary and important to be realized, especially in universities. This is due to the difficulty for students in understanding some of the basic subjects of general importance and is a prerequisite to be able to take courses productive / field of science.

Distance learning is conceptualized as learning that is carried out in separate locations so that it requires an intermediary medium to connect the two, lecturers and students. The intermediary media can be in the form of social media technology such as WhatsApp, telegram, or Facebook or it can be provided by the Government such as spada, teacher room, Zenius, kelase, etc. In accordance with the opinion of [2] that to increase effectiveness in learning, campuses are expected to provide and use information and communication technology in the form of computers, internet networks, learning media / props, or other media.

Current learning is more directed at modernization activities with the help of advanced technology in the hope that it can help students digest lecture material in an interactive, productive, effective, inspirational, constructive, and fun way. In addition, students are also expected to have life skills from the application of this technology. With this growing technological era, the learning program is directed to be able to make better use of technology. One of the uses of technology today is eLearning using the web to access it. It does not deny that because many students now have smart phones, it is easier to access them from wherever they are and anytime. The use of e-learning that is commonly developed today is to use the LMS (Learning Management System).

Maros Muslim University is one of the universities that has utilized e-Learning as a learning medium for four semesters. Especially when there was a covid-19 outbreak, all lecturers were asked to carry out distance learning. Learning activities carried out by lecturers, especially in the Mathematics Education Study Program, use applications that have been provided by the campus, namely google classroom.
Google Classroom is an application that allows the creation of classrooms in cyberspace. During the pandemic, lecturers and students at Maros Muslim University, especially the Mathematics Education Study Program, have implemented online learning using google classroom. This application can help facilitate lecturers and students in carrying out the learning process more deeply. This is because both students and lecturer can collect duties, distribute tasks, assignments in the home or anywhere without being tied to a deadline or lesson.

Lecturers who teach courses in the even semester of 2019/2020 have an interesting learning video design and various methods are used while using the google classroom application because this application actually provides an opportunity for lecturers to explore their scientific ideas for students. One of the results of the design of the lecturer learning video has been uploaded to his YouTube channel which can be seen on the link https://www.youtube.com/watch?v=_3OiAcgbhdI\&t=30 $7 \mathrm{~s}$. Lecturers have the freedom to share scientific studies and give independent assignments to students. In addition, Lecturers can also open discussion spaces for students online. However, there is an absolute prerequisite for applying Google Classroom, which requires qualified internet access. The following is the initial appearance of google classroom in the Mathematics Education Study Program.

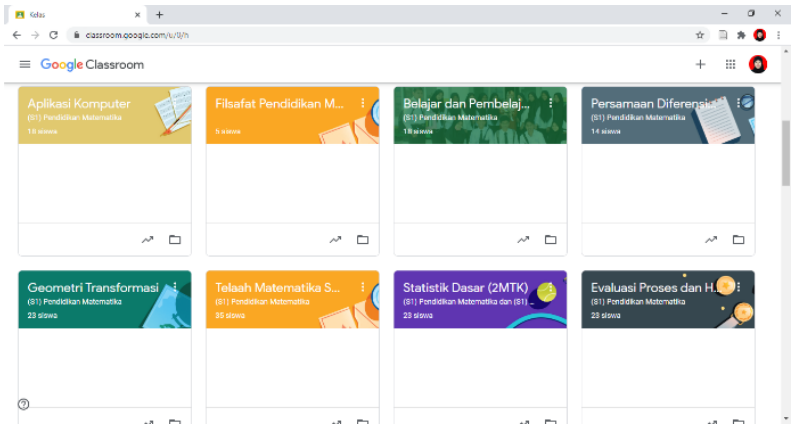

Figure 1 Initial View of Google Classroom

In the learning process that has been carried out in the even semester of 2019/2020, students are given assignments by lecturers and send the results of their reports to the google classroom application. In addition, students are also given additional material in order to understand more broadly the material that will be delivered by the lecturer. E-learning is an alternative media for providing test questions and media improvisations that do not always use printed media. Moreover, a circular from the Minister of Nadiem stated that for the odd semester 2020/2021 all tertiary institutions in all zones are required to carry out distance learning. Therefore, it is necessary to develop learning content before the implementation of distance learning. 


\section{METHOD}

The type of research that researchers use is development research where the researcher wants to create learning content in the form of digital teaching materials such as e-modules and learning videos on discrete mathematics courses. Therefore, researchers want to develop and produce learning content on discrete mathematics courses.

This research was conducted in the Mathematics Education Study Program of the FKIP Muslim University of Maros in the odd semester of 2020/2021. The subjects of this study were odd semester students programming discrete mathematics courses in the 2020/2021 academic year.

To get a research instrument that is valid, practical, and effective in this research, the development research procedure to be carried out refers to the Plomp development model. The Plomp model consists of five phases [3], namely: (1) the initial investigation phase, (2) the design phase, (3) the realization phase, (4) the test phase, evaluation and revision, and (5) the implementation phase.

The research instrument is a tool used to collect data in research. The instruments used in this study were: (1) learning implementation observation sheet, (2) discrete mathematics digital module, (3) learning videos (4) learning outcome tests and (5) student response questionnaires.

The validity of the instruments used is to validate the instruments with development procedures (stages) that refer to the opinion of [4] and [5]. To obtain data on the validity of the instrument in the form of validation formats, observation sheets, and questionnaires, the theoretical validity was investigated through expert / expert judgment [6]. Analysis practicality of an instrument of learning content distance is measured from the questionnaire responses of students that have been developed. If the percentage of student responses is $\geq$ $70 \%$, it is said to be practical. While the data analysis technique for the effectiveness test was carried out by calculating the percentage of students' learning outcomes test scores. If the percentage of student learning outcomes tests $\geq 75 \%$ it is said to be effective.

The data obtained in this study were analyzed and then used to revise the developed instruments in order to produce appropriate instruments according to the specified criteria.

\section{RESULT AND DISCUSSION}

Based on the stages of the Plomp development model used to develop digital Discrete Mathematics learning content using google classroom, there are several things that will be explained, including as follows.

\subsection{Initial Investigation Phase}

As a first step in this research, the researcher begins by conducting an initial investigation, where this step is to define and define learning needs by analyzing the objectives and limitations of the material. In this stage, identification and study of the discrete mathematics curriculum, student condition analysis, material analysis and assessment analysis are carried out.

\subsubsection{Curriculum analysis}

In this study the researchers conducted a study of the discrete mathematics curriculum regarding the learning outcomes of these study programs and subjects and it was found that the learning outcomes of discrete mathematics courses in the Mathematics Education Study Program of the FKIP Muslim University of Maros, namely after attending lectures, students were able to understand and master theoretical concepts. related to the logic of proof, mathematical induction, the principle of counting, recursive relations, and generator functions as well as basic theory about graphs in everyday life by manual and / or by using information technology either in groups or independently and respecting differences of opinion and findings other people's originals.

\subsubsection{Analysis of students}

In this case, what is meant as a student is an active student in the odd semester of the Mathematics Education Study Program of the FKIP Muslim University of Maros for the academic year 2020/2021 taking Discrete Mathematics courses. The number of students analyzed was 14 students ( 10 high ability students and 4 low ability students). Based on the results of observations during lectures in class, students who have high and low abilities give almost the same responses / responses to the learning process that occurs, where they complain about the unavailability of teaching materials in the form of modules in Discrete Mathematics learning and the lack of use of learning media used in the learning process, so that the learning process does not run optimally.

\subsubsection{Material analysis}

At this stage, an analysis of the material to be developed in the digital module is carried out. The material prepared is adjusted to the concept analysis that has been previously established. The material - material that is described in the module Digital Discrete Mathematics in Mathematics Education is, among other things: an introduction to logic, mathematical induction principle, the basic principle of calculation, generating functions, recursive relations and the basic theory of graph. This can be seen from the following competency map for courses.

\subsubsection{Assessment analysis}

This stage is carried out to determine the assessment system that is suitable for the learning being carried out, 
in this case the appropriate assessment system for the assessment of Discrete Mathematics material being taught. This analysis also makes it easier for lecturers to formulate assessment indicators to be achieved. In addition, this analysis aims to find out about the assessment system that is often used by teachers at this time. Assessment consists on the assessment results and appropriate to the achievement of the learning process, as follows:

Table 1. Learning Assessment Component

\begin{tabular}{clc}
\hline No. & Assessment Components & Score (\%) \\
\hline 1 & Assessment of results & \\
& a. Mid Test & 20 \\
& b. Final Test & 25 \\
2 & Assessment process & 10 \\
& a. Presence & 15 \\
& b. Expressing opinions in & \\
& $\quad$ discussions or \\
& $\quad$ presentations & 30 \\
\hline & c. Quiz & 100 \\
\hline
\end{tabular}

The assessment score used to measure the results of the student's knowledge test is to use the 5 Scale Benchmark Reference Assessment (PAP) approach because this approach requires a minimum percentage of mastery of student knowledge. The 5 Scale Benchmark Reference Assessment (PAP) score can be seen in table 2 below.

Table 2. Standard Reference Assessment Score (PAP) Scale 5 For Student Knowledge Test

\begin{tabular}{cccc}
\hline Alphabet. & Score & Range & Category \\
\hline A & 4 & $80-100$ & Special \\
B & 3 & $60-79$ & Good \\
C & 2 & $40-59$ & Enough \\
D & 1 & $20-39$ & Less \\
E & 0 & $0-19$ & Very Less \\
\hline
\end{tabular}

Table 2 shows that the average value of student learning outcomes after being taught discrete mathematics subject matter assisted by google classroom will be categorized as at least in the good category.

\subsection{Design phase}

At this stage, learning content design is carried out in the form of discrete mathematics e-modules and learning videos aimed at producing an initial prototype. Activity of the design is comprised of three main measures, namely the selection of media, format selection and preliminary design (preliminary design).

\subsubsection{Media selection}

At this stage, the determination and selection of the appropriate media is carried out to present the digital Discrete Mathematics module and learning videos. Based on curriculum analysis, student analysis, material analysis, assessment analysis and analysis of the availability of supporting facilities in the Mathematics Education Study Program FKIP UMMA, the media can be used to present digital modules and learning videos during distance learning so that they can be accessed by students at any time and wherever they are is google classroom, pdf reader, anyflip, kinemaster and google drive.

\subsubsection{Format selection}

The Discrete Mathematics digital module that was developed is made using an open source application, namely open office.org, thus forming a digital module in pdf format. To be able to carry out the learning process both synchronously and asynchronously, an LMS, namely google classroom, is needed so that learning activities carried out by lecturers and students can occur at different times and teaching materials can be accessed directly by students via internet facilities without any time and space restrictions. With this LMS, lecturers can send learning video files that have been compiled and the preparation process requires a kinemaster application so that the video display is more attractive and interactive. Then as a form of discussion of the material provided by the lecturer, students will be formed into several groups and to see the group discussion process, a google doc is needed so that group learning can be optimized. The following is an example of the learning content format that will be carried out using Google Classroom, which includes attendance, material and discussion forums, specifically for meeting 1 , an introduction and lecture contract.

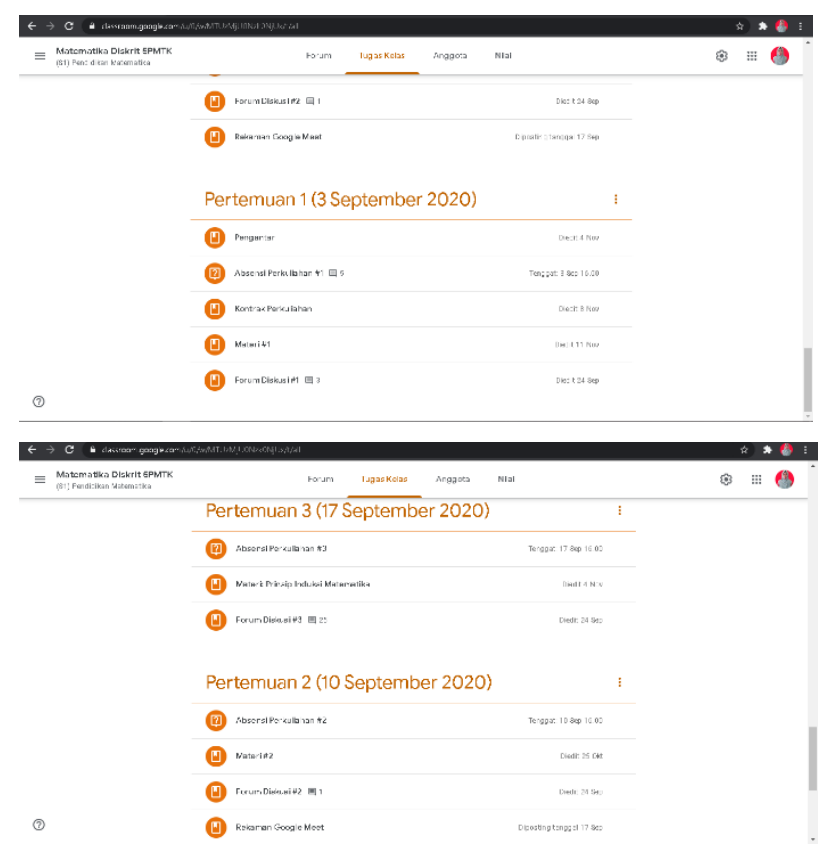




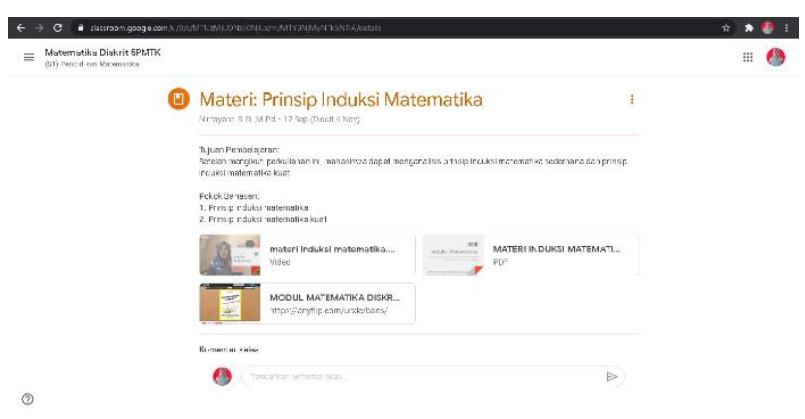

\subsubsection{Initial design}

At this design stage, the initial design of the learning content consists of a semester learning plan, a digital discrete mathematics module, learning videos, observation sheets, and student response questionnaires, instruments used to obtain the data needed in the process development and validation sheets.

The results of this initial design become a draft which must then be validated by the experts and then revised, so that the prototype- 1 is ready to be tested which becomes the research subject.

\subsection{Realization phase}

In this phase, learning tools (prototype-1) and research instruments used in limited research are made as a continuation of the design phase. The results of this phase are the semester learning plan, discrete mathematics digital modules, learning videos, observation sheets, and student response questionnaires, as well as research instruments. At this stage a prototype1 has been produced consisting of validity instruments, practicality instruments, and effectiveness instruments.

\subsection{Test, evaluation and revision phase}

On this stage of the validation of the learning content Discrete Mathematics with the hope of getting a fill / revision of experts, so that the content that can be better developed. In addition, at this stage field trials were also carried out, namely in the discrete mathematics class. Trials are carried out as a core development step which is expected to obtain research data regarding the validity, practicality and effectiveness of the product in the implementation of classroom learning. The things to do at this stage include:

\subsubsection{Validate Content Learning Discrete Mathematics}

The results of the validation carried out by two validators on the Discrete Mathematics digital module and the learning videos can be seen in table 3 below.
Table 3. Data analysis of the results of the initial prototype validity test by the validator

\begin{tabular}{clcccc}
\hline No. & $\begin{array}{l}\text { Protype } \\
\text { Type }\end{array}$ & \multicolumn{2}{c}{ Validator } & Average & Criteria \\
\cline { 3 - 4 } 1. & Semester & 3,6 & 3,8 & 3,7 & Valid \\
& $\begin{array}{l}\text { Learning } \\
\text { Plan }\end{array}$ & & & & \\
2. & $\begin{array}{l}\text { Discrete } \\
\text { Mathema } \\
\text { tics }\end{array}$ & 3,6 & 3,8 & 3,7 & Valid \\
& $\begin{array}{l}\text { Digital } \\
\text { Module }\end{array}$ & & & & \\
3. & $\begin{array}{l}\text { Learning } \\
\text { Video }\end{array}$ & 3,6 & 3,8 & 3,7 & Valid \\
4. & $\begin{array}{l}\text { Learning } \\
\text { Outcome }\end{array}$ & 3,6 & 3,8 & 3,7 & Valid \\
s Test & & & & \\
Student & 3,5 & 3,7 & 3,6 & Valid \\
& $\begin{array}{l}\text { Response } \\
\text { Question } \\
\text { naire }\end{array}$ & & & & \\
\hline
\end{tabular}

The results of the analysis in table 3 show that overall the initial prototypes, namely the semester learning plan learning tools, learning modules and videos as well as research instruments have met the valid criteria and do not need revision.

\subsubsection{Limited trial}

At this stage, a limited trial was carried out using the Discrete Mathematics digital module, instructional videos, learning outcomes tests and student response questionnaires for 14 students taking Discrete Mathematics courses. The practicality test of learning tools can be seen from the percentage of student response questionnaires that have been distributed through google classroom. The limited trial results show that student responses to the use of google classroom and its use in distance learning meet practical criteria with a percentage of $85 \%$ which is above $70 \%$. Thus the learning tools in the form of semester learning plan, learning modules and videos as well as research instruments that have been developed are declared practical. While the test of the effectiveness of learning devices can be seen from the percentage of student learning outcomes given to students subject to limited trials, this can be seen in table 4 below. 
Table 4. Recapitulation of Student Learning Outcomes Tests

\begin{tabular}{cccc} 
No. & Students Name & Score & Information \\
\hline 1 & MHS01 & 92,86 & Completed \\
2 & MHS02 & 92,86 & Completed \\
3 & MHS03 & 64,29 & Not Completed \\
4 & MHS04 & 85,71 & Completed \\
5 & MHS05 & 85,71 & Completed \\
6 & MHS06 & 92,86 & Completed \\
7 & MHS07 & 85,71 & Completed \\
8 & MHS08 & 92,86 & Completed \\
9 & MHS09 & 92,86 & Completed \\
10 & MHS010 & 85,71 & Completed \\
11 & MHS011 & 85,71 & Completed \\
12 & MHS012 & 78,57 & Completed \\
13 & MHS013 & 85,71 & Completed \\
14 & MHS014 & 92,86 & Completed \\
\hline & Average & 86,73 & \\
\hline
\end{tabular}

Information:

Completed means that the minimum completeness criteria for the predetermined student learning outcomes is above 75 .

Based on table 4 , it is found that the percentage of student learning completeness reaches $92.86 \%$, where the number of students who complete is 13 students and the remaining incomplete is 1 person. In addition, from table 2 and table 4 it is known that the average score of student learning outcomes of 86.73 is included in the special category. Therefore, the student learning outcome test that has been developed is declared effective.

\subsection{Implementation Stage}

After the Discrete Mathematics learning content is revised and said to be suitable for use by validators/ experts, the digital modules, learning videos, learning outcomes tests and student response questionnaires can be disseminated / distributed to students taking Discrete Mathematics in the Mathematics Education Study Program of FKIP University Maros Muslim. The method of distributing digital modules and learning videos is by putting them on the https://fkip.umma.ac.id/math/spada website which can be accessed by all students, so that the learning process can occur wherever the student is.

\section{CONCLUSION}

Based on the results of research and development has been done, it can be deduced as follows: (1) The results of the validity test by expert validators, semester learning plan learning tools, learning modules and videos and research instruments were declared valid. This shows that the learning tools developed are in accordance with the stages in the Plomp model. (2) To test the practicality conducted by lecturers models in distance learning can be seen from the response of students and obtained $\mathrm{s}$ choir percentage of practicality above $70 \%$, (3) Content learning discrete mathematics can effectively improve mathematical ability is most students it is seen from the acquisition of a percentage completeness is $92,86 \%$. Thus, discrete mathematics learning content consisting of semester learning plan learning tools, learning modules and videos as well as research instruments is declared valid, practical and effective

\section{AUTHORS' CONTRIBUTIONS}

In this study, the first author is responsible for carrying out and reporting the results of the implementation of this research to the campus, the second author, the third and fourth authors are in charge of analyzing the research data, the fifth and sixth authors assist the first author in collecting data and observing the implementation of the learning model in the classroom.

\section{ACKNOWLEDGMENTS}

The author would like to thank all validators and observers who have helped this learning process and especially to FKIP, Muslim University of Maros as a place for the author's research.

\section{REFERENCES}

[1] G. A. D. Sugiharni, "Pengembangan Modul Matematika Diskrit Berbentuk Digital Dengan Pola Pendistribusian Asynchronous Menggunakan Teknologi Open Source," Jurnal Nasional Pendidikan Teknik Informatika (JANAPATI), vol. 7, no. 1, pp. 58-72, Mei 2018, doi: 10.23887/janapati.v7i1.12667.

[2] I. K. Darma, I. G. M. Karma, dan I. M. A. Santiana, "Blended Learning, Inovasi Strategi Pembelajaran Matematika di Era Revolusi Industri 4.0 Bagi Pendidikan Tinggi," Prisma: Prosiding Seminar Nasional Matematika, vol. 3, pp. 527-539, 2020.

[3] T. Plomp, Development research on/in educational development. Enschede: Twente University, 2001.

[4] R. J. Cohen dan M. E. Swerdlik, Psychological testing and assessment: An introduction to test and measurement (6th ed.). New York: McGraw Hill, 2005.

[5] D. Mardapi, Teknik Penyusunan Instrumen Tes dan non Tes. Yogyakarta: Mitra Cendia Press, 2008.

[6] Ruslan, "Validitas Isi," Buletin Pa'biritta No. 10 Tahun VI September 2009, 2009. 